\title{
ANTHOCYANINS PROFILES OF SOME AUTOCHTONOUS GRAPEVINE CULTIVARS FOR RED WINES, CULTIVATED AT DRĂGĂȘANI, ROMÂNIA
}

\author{
F. Tutulescu1* and A. Popa ${ }^{1}$, \\ 1University of Craiova Horticulture Faculty, 13 A.I. Cuza, Craiova, Romania \\ * Corresponding author email: felixdragomir@yahoo.com
}

\begin{abstract}
The Dragasani vineyard is one of the most ancient existing in Romania being famous for obtaining red and white wines of the highest quality. The present study has performed during five years (2005-2009), focusing on the anthocyanin profiles of the autochthonous Novac grapevine cultivar; in comparison with Cabernet Sauvignon cultivar which, also provides wines of high quality. The obtained results put into evidence, $_{\bar{j}}$ a special potential and chromatic structure in case of the grapes and wines characteristics for these autochthonous cultivars, which are very closed to those shown by the Cabernet Sauvignon. For all the cultivars studied, the amounts of cationical flavidium within the anthocyanin matter do keep continuously was growing, while acidity decreased and glucides was accumulated. However, at some moment, these synthesis indices of the cromatical structure's quality begin to decline. Depending of the viticultural year it is the genetical nature of the respective anthocyanin pigments to differentiate through the involvements of each of the 3 categories of pigments (yellow, red or blue). During the wine's evolution (maturation and aging), due to the modification of its cromatical structure, the ratio between the yellow and red pigments does confer to the wine a colour nuance which continues to increase, significantly improving the wine's visual attraction. For the autochthonous grapevine cultivars for red wines, their antocyanins potential their respective qualities do enable us to state that on the basis of the quality of the raw materials, wine types of high qualities could be created, being so endowed that they could bear as well an origin denomination.
\end{abstract}

Keywords: wine, cromatic structure, pigments, anthocyanins

\section{INTRODUCTION}

The vineyard of Dragasani is one of the most ancient in Romania. It is a former Dacian vineyard, famous for its vocation which allowed to obtain wines of the highest quality, as well as others aromatic or white ones. The Dragasani vineyard, in the matter of its oenoclimate, is situated within the A3 zone. Its viticultural centers are located upon hills. They mostly produce red and aromatic wines while, as a subsidiary specialty, they also provide white wines. The vineyard benefit from climate opportunities that allow, the synthesis in the grapes of whatever among its necessary constituents, no matter how complex their chemical structure might be. However, the abundance of these opportunities is not accompanied by climate's toughness's, that could in any case simultaneously, cause deteriorations of their constitutive harmony, by wastes or degradations (Popa, A., 2007; 2012). The Dragasani red wines are defined through more stamina than others, by the richness of their colours, the beauty they have in terms of their hue by their great propension for aging. Their main virtues are related to the way in which these wines 
achieve an accurate expression of the quality assets held by the types from which they comes (Macici, M., 2008). The delicate specific red wines are obtained from grapes cultivars such as: Cabernet Sauvignon, Pinot Noir, Fetească Neagră. More recently, at Drăgășani Station for Viticulture and Oenology: Negru de Drăgășani and Novac grapevine cultivars were created. These two newly created cultivars have as parents Negru Vartos (an ancient Romanian cultivar) and from Saperavi.

The studies performed concerning the amounts of anthocyanins that exist in grapes, musts and wines have pointed out the items that determine their accumulation in grapes, the structure in which they are aggregated, the role they must play in the hygienical and sanitary creation of status value of wines (Ribereau Gayon G., 1991, Fisher U., 1998, Vivas de Gaulejac N., et all., 2001, Otteneder H et all. 2001, Burus J et all., 2002, Saurey R et all. 2007, Teodorescu St., 1957, Teodorescu St. et all., 1987, Carbonneau A., 1993, Hamatschek J., 1991, Onescu Janina, 2008, Kontek Adriana, 1987, Ţârdea C et all., 2000; Cotea D.V. et all., 2009).

\section{MATERIALS AND METHODS}

The antocyanes from the berries of the grapes were determined through the Poissant Leon method. From the red wines anthocyanins were determined by spectrophotometrical method, through the $\mathrm{pH}$ difference. The difference between the optical densities of solutions with two different $\mathrm{pH}$, read at $520 \mathrm{~nm}$ is directly proportional to the amount of anthocyanins contained by the wine. The concentration of anthocyanins was established following the standardizing graph curve, drawn upon the ground of collected data, and its expression is done in $\mathrm{mg} / \mathrm{L}$. The red wines'colour was determined in the visible domain through a spectrophotometry at the wavelengths of $420 \mathrm{~nm}$ (yellow component, $520 \mathrm{~nm}$, for red component and at $620 \mathrm{~nm}$ for blue component, color intensity, hue, were calculated as follows:

Ic = DO $420 \mathrm{~nm}+$ DO $520 \mathrm{~nm}+$ DO $620 \mathrm{~nm}$

$\mathrm{Nc}=\mathrm{DO} 420 \mathrm{~nm} / \mathrm{DO} 520 \mathrm{~nm}$

$\mathrm{dA}=$ D0 $520 \mathrm{~nm}-($ DO $420 \mathrm{~nm}+$ DO $620 \mathrm{~nm} / 2$ )/D0520 nm

The anthocyanins 'ratio combined with tannins (pvp\%) and the polymerized pigments pp\% was estimated. In order to follow the evolution of the grapes'ripening process, the methods recommended by the O.I.V. was applied.

The wines were obtained by the classical method of red winemaking. The wine's maturation was realized in oak tree wood vases (bariques) with a capacity of 220 litres, while the aging was made in bottles. Within the storage space, a temperature of about $10-12^{\circ} \mathrm{C}$ was ensured.

\section{RESULTS AND DISCUSSIONS}

In matters of quantity and quality, the colour of red depends not only on the anthocyanins content of the grapes which are the raw material, but also on the ratio of the primary winemaking, which is found by the oenological quantity called the technological reserve.

For the studied parameters, the obtained results, concerning the anthocyanins content, their extractability and the technological reserve are presented in Table 1 The data's ensemble analysis eloquently points out the fact that the Cabernet Sauvignon cultivar has the capacity to exploit the conditions offered by the Dragasani vineyard. 
Table 1. Anthocyanins Contents, Extractability and Technological Reserve for anthocyanins for Some Grapevine Cultivars for Red Wines Cultivated in the Vineyard of Dragasani, Romania

(Limits and Average Mean for 5 Years, 2005-2009)

\begin{tabular}{|c|c|c|c|c|c|}
\hline \multirow[t]{2}{*}{ Parameter } & \multirow{2}{*}{$\begin{array}{l}\text { Moment of } \\
\text { determining }\end{array}$} & \multicolumn{4}{|l|}{ Cultivar } \\
\hline & & $\begin{array}{l}\text { Cabernet } \\
\text { Sauvignon }\end{array}$ & $\begin{array}{l}\text { Feteasca } \\
\text { Neagra }\end{array}$ & $\begin{array}{ll}\text { Negru de } \\
\text { Dragasani }\end{array}$ & Novac \\
\hline \multirow{3}{*}{$\begin{array}{l}\text { Anthocyanins } \\
\mathrm{mg} / \mathrm{kg} \text { of } \\
\text { grapes }\end{array}$} & Full maturity & $\begin{array}{l}1354-1495 \\
1402\end{array}$ & $\begin{array}{l}1061-1164 \\
1099\end{array}$ & $\begin{array}{l}1199-1270 \\
1224\end{array}$ & $\begin{array}{l}1384-1470 \\
1398\end{array}$ \\
\hline & $\begin{array}{l}\text { Phenolic } \\
\text { anthocyanins } \\
\text { maturity }\end{array}$ & $\begin{array}{l}1461-1570 \\
1507\end{array}$ & $\begin{array}{l}1208-1346 \\
1276\end{array}$ & $\begin{array}{l}1296-1460 \\
1381\end{array}$ & $\begin{array}{l}1422-1518 \\
1485\end{array}$ \\
\hline & $\begin{array}{l}\text { Technological } \\
\text { maturity }\end{array}$ & $\begin{array}{l}1425-1540 \\
1470\end{array}$ & $\begin{array}{l}1203-1307 \\
1255\end{array}$ & $\begin{array}{l}1274-1415 \\
1330\end{array}$ & $\begin{array}{l}1487-1500 \\
1494\end{array}$ \\
\hline \multirow{3}{*}{$\begin{array}{l}\text { Anthocyanins } \\
\text { extractability } \\
\%\end{array}$} & Full maturity & $\begin{array}{l}48.9-52 \\
50.2\end{array}$ & $\begin{array}{l}48.6-50.2 \\
49.7\end{array}$ & $\begin{array}{l}47-49.5 \\
48\end{array}$ & $\begin{array}{l}45.9-49.1 \\
47.3\end{array}$ \\
\hline & $\begin{array}{l}\text { Phenolic } \\
\text { anthocyanins } \\
\text { maturity }\end{array}$ & $\begin{array}{l}53.1-56 \\
54.4\end{array}$ & $\begin{array}{l}50.6-54 \\
52.5\end{array}$ & $\begin{array}{l}52-53 \\
52.5\end{array}$ & $\begin{array}{l}48.6-53.1 \\
52.1\end{array}$ \\
\hline & $\begin{array}{l}\text { Technological } \\
\text { maturity }\end{array}$ & $\begin{array}{l}54.8-57.3 \\
56.1\end{array}$ & $\begin{array}{l}53.4-56.7 \\
54.9\end{array}$ & $\begin{array}{l}52.6-56 \\
54.5\end{array}$ & $\begin{array}{l}52-56 \\
55\end{array}$ \\
\hline \multirow{3}{*}{$\begin{array}{l}\text { Anthocyanins } \\
\text { extractabile } \\
\text { from grapes } \\
\text { (technological } \\
\text { reserve) mg }\end{array}$} & Full maturity & $\begin{array}{l}662.1-769 \\
705\end{array}$ & $\begin{array}{l}506.1-589 \\
546\end{array}$ & $\begin{array}{l}558-622 \\
584\end{array}$ & $\begin{array}{l}638-685 \\
666\end{array}$ \\
\hline & $\begin{array}{l}\text { Phenolic } \\
\text { anthocyanins } \\
\text { maturity }\end{array}$ & $\begin{array}{l}776-869 \\
820\end{array}$ & $\begin{array}{l}609-725 \\
665\end{array}$ & $\begin{array}{l}666-780 \\
731\end{array}$ & $\begin{array}{l}687-795 \\
761\end{array}$ \\
\hline & $\begin{array}{l}\text { Technological } \\
\text { maturity }\end{array}$ & $\begin{array}{l}781-874 \\
825\end{array}$ & $\begin{array}{l}639-733 \\
687\end{array}$ & $\begin{array}{l}668-789 \\
709\end{array}$ & $\begin{array}{l}769-832 \\
810\end{array}$ \\
\hline
\end{tabular}

At its full maturity even in the viticultural years which, in climate matters, should present deficits, due to the kind's genetical nature, within the grapes' berries might be accumulated a concentrations in anthocyaninswhich would be enough to obtain red wines with a convenient colouring. In the viticultural years with a lot of heat and light, the anthocyanins amounts almost reach up to $1495 \mathrm{mg} / \mathrm{kg}$ of grapes, so it is a higher ratio. At the phenolic maturity, a phenol phase which occurs after full maturity, the grapes' contents in anthocyanins increases to high values.

At technological maturity, for all the the period the phenolic maturity was registered, but still they are excellent for obtaining red wines with valuable chromatic characteristics of high quality chosen.

For the Cabernet Sauvignon, the rations of extractible anthocyanins from the grapes' has been touched at maturation, as well as when it passed from full maturity to technological maturity. According to the content of anthocyanins's in grapes and the degree of their extraction, the level of the technological reserve also increase.

The data about the technological reserve show that richly colored red wines can also be obtained in situation where Cabernet Sauvignon grapes are harvested at their full maturity, a phenolic phase when the production reaches its stage of course if the other composition corresponds to the type of wine we would like to get it. If the Cabernet Sauvignon grapes have to be harvested at their phenolic and technological maturity, they would result in intensely coloured wines, the respective colour being comparable to that of similar wines issued from other viticultural areas which are famous for this production line. Sauvignon.

For the Feteasca Neagra grapes, the anthocyanins potential is lower that of Cabernet 
The diference is dictated both by the genetical nature of respective cultivar but significantly by the high quantities of berries skins, since the Cabernet Sauvignon berries is smaller than that of Feteasca Neagra.

In the Feteasca Neagra grapes, the anthocyanins potential display chromatic characteristics which are influenced, as well as in the case of Cabernet Sauvignon, by the climate circumstances offered by the respective viticultural harvest year.

For all the three phenolic phases of the grape's maturation, the anthocyanins amounts have evolved increasingly, both from one year to another and, within a same year, they increased from full maturity to technological maturity.

For the extractible anthocyanins, the ratios increased from full maturity to technological one, even if for the grape berries of Feteasca Neagra, the anthocyanins sometimes decresed, between the phenolic maturity and the technological one.

For all maturities, either completely phenolic or technological, the registered technological reserve is able to ensure, for Feteasca Neagra wines, the required necessary colour to be included in superior categories, a place that is also guaranteed due to the other characteristics of the grapes, either in technology or in composition. Concerning the biological synthesis and accumulation capacities of the grapes regarding to the colouring matter from anthocyanins, at the Negru de Dragasani cultivar their they are not much smaller in the case of Cabernet Sauvignon cultivar.

The study of the anthocyanins content in grapes and that of their extractability recorded at the phenolic and technological maturity, allows us to conclude that the obtaining wines will have a good coloring intensity and beautiful hue.

In conditions of grape harvests that often exceed $9000 \mathrm{~kg} / \mathrm{ha}$, for the Novac cultivar the anthocyanins' content is quite closed to that of the Cabernet Sauvignon cultivar.

Compared to this latter for Novac grapes of the Novac kind, the degree of anthocyanins extractability is lower. For this reason, technological reserves are also smaller, but not with a considerable difference. For each of the stages of maturation of the Novac grapes, technological reserves are considered to be particularly favourable for obtaining of some intensity coloured wines, situated in this sense, near those of Cabernet Sauvignon and beyond those of Feteasca Neagra and Negru de Dragasani.

As a defining advantage for the quality of these types of wines, the red wines' colour is edified not only on the quality of anthocyanins matter in its constitution, but also by its chromatic structure, established by the the participation of the three categories of pigments (yellow, red and blue). Table 2 presents the results obtained.

At Cabernet Sauvignon, for the whole period of time, the yellow component was situated under $30 \%$. The highest value of this component is usually recorded in viticultural years with an excess of precipitations but not sunny enough. The red component appears in higher proportions in the good viticultural years in matters of climate meaning warm and under a good light. The blue component seems to benefit from less favourable climate conditions. At the Feteasca Neagra grapes the chromatic structure of the anthocyanins colors matter as a whole, is characterized by a more accentued variability of the three components.

The yellow and the red components show higher values during viticultural years with lots of rains and less insolation. The complex anthocyanic chromatic structure from the grapes of the Feteasca Neagra cultivar, as a whole, proves that for the various climate conditions existing in several viticultural years, a corresponding variation is created, especially for the yellow and blue components, which impose conditions on the indices of the red component.

The first statement which can be presented on the quantized ensemble of the chromatic sizes which are specific to the chromatic structure of the anthocyanin extractions 
from the grapes of the Negru de Dragasani refers to a certain persistence over time of the yellow component, less than $30 \%$, for all the studied years that are warm and sunny, the blue pigments present higher rations in the rainy years, more chilly and with shorter isolation time during the phenolic phases of the grapes maturation. In grapes of the Novac cultivar, the chromatic structure of the anthocyanins matter was significantly similar to that of Negru de Dragasani grapes. At technological maturity, the sizes of the three components from the structures of the colouring matters within grapes are are found in the levels of the chromatic assets, represented by the colouring intensity of color (Ic), the hue (the colour's tonality - Nc) and by the flaviliumcations (dA\%).

Table 2. Cromatic Structure of the Anthocyanins Complex from the Grapes of the Grapes Cultivars for

Red Wines, Cultivated in the Vineyard Dragasani, Romania

(Limits and Average Mean for Five Years, 2005-2009) at Their Technological Maturity

\begin{tabular}{|l|l|l|l|l|l|}
\hline Pigments & \multirow{2}{*}{ Specification } & \multicolumn{4}{|c|}{ Cultivar } \\
\cline { 3 - 6 } & & $\begin{array}{l}\text { Cabernet } \\
\text { Sauvignon }\end{array}$ & Feteasca Neagra & $\begin{array}{l}\text { Negru de } \\
\text { Dragasani }\end{array}$ & Novac \\
\hline Yellow & D.0.420 & $0.807-0.915$ & $0.69-0.809$ & $0.796-0.886$ & $0.873-0.898$ \\
& & 0.850 & 0.769 & 0.828 & 0.887 \\
\cline { 2 - 6 } & $\%$ & $29.5-29.7$ & $29.95-31.14$ & $29.05-29.70$ & $28.57-29.31$ \\
& & 28.9 & 31.05 & 29.36 & 29 \\
\hline Red & D.0.520 & $1.649-1.919$ & $1.406-1.579$ & $1.614-1.850$ & $1.807-1.920$ \\
& & 1.809 & 1.519 & 1.725 & 1.867 \\
\cline { 2 - 6 } & $\%$ & $60.39-62.6$ & $60.7-62$ & $60.2-61.29$ & $60.44-61.38$ \\
& & 61.7 & 61.2 & 60.87 & 67 \\
\hline \multirow{3}{*}{ Blue } & D.0.620 & $0.275-0.287$ & $0.202-0.216$ & $0.269-0.288$ & $0.299-0.319$ \\
& & 0.279 & 0.210 & 0.279 & 0.309 \\
\cline { 2 - 6 } & $\%$ & $9.19-10.1$ & $7.94-9.20$ & $9.56-10.20$ & $9.66-10.40$ \\
& & 9.62 & 8.53 & 9.85 & 10.10 \\
\hline
\end{tabular}

Table 3 presents the solid reasons for which the grapes for red wines that are cultivated at Dragasani have a vocation for obtaining wines of high quality. The color intensity, the color's hue and the flaviliumcations of Cabernet Sauvignon wines place them in the category of great red wines. The Novac and Negru de Dragasani wines, in terms of their richness and color's beauty are close to those of Cabernet Sauvignon. All these obtained results lead us to the foresight the completion of the Dragasani red wines.

Table 3. Cromatic Characteristics of the Anthocyanins Extracts from the Grapes for Red Wines, Cultivated in the Vineyard of Dragasani Romania (Limits and Average Mean for Five Years, 20052009) at Technological Maturity

\begin{tabular}{|c|c|c|c|c|}
\hline \multirow{2}{*}{$\begin{array}{l}\text { Chromatic } \\
\text { characteristics }\end{array}$} & \multicolumn{4}{|l|}{ Cultivar } \\
\hline & $\begin{array}{l}\text { Cabernet } \\
\text { Sauvignon }\end{array}$ & $\begin{array}{l}\text { Feteasca } \\
\text { Neagra }\end{array}$ & $\begin{array}{ll}\text { Negru } & \text { de } \\
\text { Dragasani } & \end{array}$ & Novac \\
\hline Color intensity (Ic) & $\begin{array}{l}2.735-3.140 \\
2.940\end{array}$ & $\begin{array}{l}2.305-2.589 \\
2.570\end{array}$ & $\begin{array}{l}2.760-3.20 \\
2.83\end{array}$ & $\begin{array}{l}2.99-3.135 \\
3.080\end{array}$ \\
\hline Color tonality (Tc) & $\begin{array}{l}0.474-0.490 \\
0.470\end{array}$ & $\begin{array}{l}0.490-0.518 \\
0.499\end{array}$ & $\begin{array}{l}0.475-0.493 \\
0.483\end{array}$ & $\begin{array}{l}0.479- \\
0.485 \\
0.467\end{array}$ \\
\hline Flaviliumcations & $\begin{array}{l}67.25-70.66 \\
69.80\end{array}$ & $\begin{array}{l}66.51-67.89 \\
67.35\end{array}$ & $\begin{array}{l}66.92-70.65 \\
69.66\end{array}$ & $\begin{array}{l}67.26-68.7 \\
68.2\end{array}$ \\
\hline
\end{tabular}

The evolution of the various forms of the anthocyanins, the evolution in time of the elements of the chromatic structure, the evolution in time of the chromatic characteristics of the Cabernet Sauvignon wines are presented in Tables 4, 5 and 6. 
An analysis in time of the chromatic elements in their evolution, starting with the separation of the must's fractions up to the age of 18 months underlines: the continuous decrease of the content of total anthocyanins, the continuous increase of the amount of anthocyanins combined with tannins, as well as the continuous increase of polymerized pigments, facts that are proven by the indices Antocyans combined with tannins (pvp), respectively Polymerized pigments (pp). If we we had to compare the data for every stage of the evolution, we would notice the lower proportion for the combination of the anthocyanins for the aging process, in relation to the ratios from the maturation's stages.

The evolution of the pvp (\%) index is another evidence attesting to these facts. The components of the anthocyanins complex also evolve, starting with the phases' separation up to the wine's age of 18 months: the yellow component is continuously increasing; the red component, taken into consideration for each of the stages, is on a decreasing trend: the blue component presents an evolution lacking constance, which is oscillating through ups and downs. The wine's chromatic assets evolve as: follows: the Ic $=$ color intensity decreases continously; the $\mathrm{Nc}=$ the color tonality or nuance is continuously increasing: the flaviliumcations at first increase slightly, between separation of the phases and the wine's age of three mounts: further during the maturation and the aging processes, they progressively diminish from one stage to another.

Table 4. Evolutions of Various Forms of anthocyanins from the Cabernet Sauvignon Wine, Dragasani, Harvest of 2007

\begin{tabular}{|c|c|c|c|c|c|c|c|}
\hline \multirow{3}{*}{$\begin{array}{c}\text { Oenological anthocyanins } \\
\text { sizes }\end{array}$} & \multirow{3}{*}{$\begin{array}{l}\text { At the } \\
\text { separati } \\
\text { on of } \\
\text { the } \\
\text { must's } \\
\text { phases }\end{array}$} & \multicolumn{6}{|c|}{ Age of wines (months) } \\
\hline & & \multicolumn{4}{|c|}{ Maturation } & \multicolumn{2}{|c|}{ Aging } \\
\hline & & 3 & 6 & 9 & 12 & 15 & 18 \\
\hline Total amount of anthocyanins (mg/l) & 808 & 778 & 759 & 722 & 676 & 602 & 591 \\
\hline Free anthocyanins (mg/l) & 750.6 & 690 & 591.3 & 457.7 & 383.3 & 319.7 & 302.6 \\
\hline Free anthocyanins (\%) & 92.9 & 88.7 & 77.9 & 63.4 & 56.7 & 53.1 & 51.2 \\
\hline Combined anthocyanins (mg/l) & 57.4 & 87.9 & 167.7 & 264.3 & 292.7 & 282.3 & 288.4 \\
\hline Combined anthocyanins (\%) & 7.1 & 11.3 & 22.1 & 26.6 & 43.3 & 46.9 & 48.8 \\
\hline index pvp \% & 11 & 20 & 27 & 31 & 34 & 36 & 37 \\
\hline index pp & 8 & 32 & 34 & 38 & 42 & 44 & 50 \\
\hline
\end{tabular}

index pvp = Antocyans combined with tannins

index $\mathrm{pp}=$ Polymerized pigments

Table 5. Evolution in Time of the Elements of Chromatic Structure for the Wine of Cabernet Sauvignon, Dragasani, Harvest 2007

\begin{tabular}{|c|c|c|c|c|c|c|c|}
\hline \multirow{3}{*}{$\begin{array}{l}\text { Elements of chromatic } \\
\text { structure of the } \\
\text { anthocyanins complex }\end{array}$} & \multirow{3}{*}{$\begin{array}{l}\text { At the } \\
\text { separation of } \\
\text { the must's } \\
\text { phases }\end{array}$} & \multicolumn{6}{|c|}{ Age of wines (months) } \\
\hline & & \multicolumn{4}{|c|}{ Maturation } & \multicolumn{2}{|c|}{ Aging } \\
\hline & & 3 & 6 & 9 & 12 & 15 & 18 \\
\hline D. $0.420 \mathrm{~nm}$ & 0.486 & 0.470 & 0.446 & 0.436 & 0.410 & 0.394 & 0.373 \\
\hline D. $0.520 \mathrm{~nm}$ & 0.916 & 0.880 & 0.730 & 0.706 & 0.657 & 0.625 & 0.580 \\
\hline D. $0.620 \mathrm{~nm}$ & 0.210 & 0.199 & 0.180 & 0.177 & 0.170 & 0.166 & 0.152 \\
\hline Yellow pigments \% & 30.148 & 30.34 & 32.89 & 33.06 & 33.14 & 33.25 & 33.76 \\
\hline Red pigments $\%$ & 56.823 & 56.81 & 53.83 & 53.52 & 53.11 & 52.74 & 52.49 \\
\hline Blue pigments $\%$ & 13.027 & 12.85 & 13.27 & 13.42 & 13.74 & 14.50 & 13.75 \\
\hline
\end{tabular}

At the Novac wines, the evolution of the anthocyanins forms, of the elements of the chromatic structure and of the chromatic assets are very similar to those of Cabernet 
Sauvignon wines (Tables 7, 8 and 9), with the exception of rythms and durations, which are mostly different.

Table 6. Evolution in Time of the Chromatic Assets of the Cabernet Sauvignon Wine, Dragasani Harvest, 2007

\begin{tabular}{|c|c|c|c|c|c|c|c|}
\hline \multirow{3}{*}{$\begin{array}{l}\text { Chromatic } \\
\text { characteristics of the } \\
\text { wine }\end{array}$} & \multirow{3}{*}{$\begin{array}{l}\text { At the } \\
\text { separation of } \\
\text { the must's } \\
\text { phases }\end{array}$} & \multicolumn{6}{|c|}{ Age of wine (months) } \\
\hline & & \multicolumn{4}{|c|}{ Maturation } & \multicolumn{2}{|c|}{ Aging } \\
\hline & & 3 & 6 & 9 & 12 & 15 & 18 \\
\hline Color intensity (Ic) & 1.612 & 1.549 & 1.356 & 1.319 & 1.237 & 1.185 & 1.105 \\
\hline Color tonality (Tc) & 0.530 & 0.534 & 0.610 & 0.617 & 0.624 & 0.630 & 0.643 \\
\hline Flaviliumcations & 61.91 & 62.03 & 57.09 & 56.64 & 55.86 & 55.20 & 54.82 \\
\hline
\end{tabular}

Table 7. Evolutions of Various Forms of Antocyanes from the NovacWine, Dragasani, Harvest of 2007

\begin{tabular}{|c|c|c|c|c|c|c|c|}
\hline \multirow[b]{3}{*}{$\begin{array}{c}\text { Oenological anthocyanins } \\
\text { sizes }\end{array}$} & \multirow{3}{*}{$\begin{array}{l}\text { At the } \\
\text { separati } \\
\text { on of } \\
\text { the } \\
\text { must's } \\
\text { phases }\end{array}$} & \multicolumn{6}{|c|}{ Age of wines (moths) } \\
\hline & & \multicolumn{4}{|c|}{ Maturation } & \multicolumn{2}{|c|}{ Aging } \\
\hline & & 3 & 6 & 9 & 12 & 15 & 18 \\
\hline Total amount of anthocyanins (mg/l) & 821 & 784 & 769 & 730 & 667 & 651 & 635 \\
\hline Free anthocyanins (mg/l) & 739.7 & 582.5 & 542.9 & 478.1 & 382.2 & 358.7 & 341 \\
\hline Free anthocyanins (\%) & 90.1 & 74.3 & 70.6 & 65.5 & 57.3 & 55.1 & 53.7 \\
\hline Combined anthocyanins (mg/l) & 81.3 & 201.5 & 226.1 & 251.9 & 284.8 & 292.3 & 294 \\
\hline Combined anthocyanins (\%) & 9.9 & 25.7 & 29.4 & 34.5 & 42.7 & 44.9 & 46.3 \\
\hline Indice index pvp(\%) & 10 & 24 & 28 & 30 & 33 & 34 & 35 \\
\hline Indice index pp & 9 & 30 & 32 & 36 & 38 & 40 & 41 \\
\hline
\end{tabular}

Indice index pvp = Antocyans combined with tannins

Indice index $\mathrm{pp}=$ polymerized pigments

Table 8. Evolution in Time of the Chromatic Assets of the Novac Wine, Dragasani Harvest, 2007

\begin{tabular}{|c|c|c|c|c|c|c|c|}
\hline \multirow{3}{*}{$\begin{array}{l}\text { Elements of chromatic } \\
\text { structure of the } \\
\text { anthocyanins complex }\end{array}$} & \multirow{3}{*}{$\begin{array}{l}\text { At the } \\
\text { separation } \\
\text { of the } \\
\text { must's } \\
\text { phases }\end{array}$} & \multicolumn{6}{|c|}{ Age of wines (months) } \\
\hline & & \multicolumn{4}{|c|}{ Maturation } & \multicolumn{2}{|l|}{ Aging } \\
\hline & & 3 & 6 & 9 & 12 & 15 & 18 \\
\hline D. $0.420 \mathrm{~nm}$ & 0.508 & 0.496 & 0.470 & 0.451 & 0.440 & 0.436 & 0.430 \\
\hline D.0. $520 \mathrm{~nm}$ & 0.936 & 0.901 & 0.830 & 0.795 & 0.743 & 0.735 & 0.721 \\
\hline D. $0.620 \mathrm{~nm}$ & 0.231 & 0.227 & 0.204 & 0.190 & 0.183 & 0.180 & 0.173 \\
\hline Yellow pigments (\%) & 30.33 & 30.54 & 31.25 & 31.41 & 32.21 & 32.27 & 32.48 \\
\hline Red pigments (\%) & 55.88 & 55.48 & 55.19 & 55.36 & 54.39 & 54.40 & 54.46 \\
\hline Blue pigments (\%) & 13.79 & 13.98 & 13.56 & 13.23 & 13.40 & 13.32 & 13.06 \\
\hline
\end{tabular}

Table 9. Evolution in Time of the Chromatic Assets of the NovacWine, Dragasani Harvest, 2007

\begin{tabular}{|c|c|c|c|c|c|c|c|}
\hline \multirow{3}{*}{$\begin{array}{l}\text { Chromatic assets of the } \\
\text { wine }\end{array}$} & \multirow{3}{*}{$\begin{array}{l}\text { At the } \\
\text { separation } \\
\text { of the } \\
\text { must's } \\
\text { phases }\end{array}$} & \multicolumn{6}{|c|}{ Age of wine (months) } \\
\hline & & \multicolumn{4}{|c|}{ Maturation } & \multicolumn{2}{|l|}{ Aging } \\
\hline & & 3 & 6 & 9 & 12 & 15 & 18 \\
\hline Colouring intensity (Ic) & 1.675 & 1.624 & 1.504 & 1.436 & 1.366 & 1.351 & 1.324 \\
\hline Colour's tonality (Tc) & 0.542 & 0.550 & 0.566 & 0.567 & 0.592 & 0.593 & 0.596 \\
\hline Flaviliumcations (dA\%) & 60.56 & 59.89 & 59.35 & 59.70 & 58.10 & 58.07 & 58.21 \\
\hline
\end{tabular}


All these values of the chromatic sizes confirm the vocation for aging of the Novac wines.

\section{CONCLUSIONS}

- $\quad$ Studies carried out on the anthocyanins profile of some autochtonous grapes cultivars for red wines which are cultivated at Dragasani have pointed out, once again, the vocation of obtaining red wines of superior quality owned by this vineyard, as well as their genetic potential of which have the cultivars of Feteasca Neagra, Novac and Negru de Dragasani, allowing them to prosper into the paedo-climatic circumstances of Dragasani;

- $\quad$ The antocyanic profiles of the autochtonous cultivars Feteasca Neagra, Negru de Drasani and Novac in comparison with those of the Cabernet Sauvignon which at Dragasani provides wines of very high quality present some similar values;

- The participating of the three categories of pigments (yellow, red and blue) was proven to be a genetical character, which is dependent, in its size, upon the climates' conditions;

- $\quad$ During the wine's evolution (maturation and aging) the chromatic characteristics (the color's intensity and tonality) reach the valves that are the features of the great red wines;

- $\quad$ Amoung the sorts of grapes assortment for red wines existing at Dragasani, Feteasca Neagra, Negru de Dragasani and Novac cultivars should achieve an important weight.

\section{REFERENCES}

1. Burns J., Landrault N., Mullen W., Teissedre P.L., Lean M.E.J., Crozier A.(2002). Variation in the profile and content of anthocyanins in Wines made from Cabernet Sauvignon and hybrid grapes. Congres O.I.V

2. Carbonneau A. (1993)Facteur de qualité - la richesse en sucres. La Progrés Agric. Vitic,nº9, p.205-206

3. Cotea D.V. CristinelZanoaga, CoteaV.Valeriu. (2009). Tratat de Oenochimie.Ed. AcademieiRomane, vol.I, p.176246

4. Fisher U. (1998). Anthocyaneaktuelbeleuchtet von ziegelrotbisPurpur. Das Deutsche WienmagazinAllemagne, n19, p.18-2.

5. Otteneder H., Brigitte Holbach, Marx R., Zimmer M. (2001). Identification of the grape cultivar in red wine by means of the anthocyanin composition. Congres O.I.V., p.181-191.

6. Onescu Janina. (2008). Studiulprofiluluiantocianic al soiurilorstrugurilornegri din Oltenia. Teza de doctorat, Univ. Craiova.

7. Popa A. (2007). Arealeleviticole din Oltenia-Romania cu vocative pentruobtinereavinurilor de calitate cu denumirede originecontrolata(D.O.C). Analele USAMV ClujNapoca,SeriaHorticultura.

8. Saurez R., Bartolome M., Gomez Cordoves C. (2007) Composicionfenolicantocianica y no antocianica de vinos Merlot de clones diferentes. XXIX CongressoMondialedellaVigna e del Vino O.I.V, Spain, Logrono, 25-30 giugno.

9. Vivas De Gaulejac Natalie, Nonier Marie Francoise, Guerra., C. (2001). Anthocyanin in grapes skins during maturation of VitisviniferaL.Cv Cabernet Sauvignon and Merlot from different Bordeaux terroirs. Journal International des sciences de la Vigneet du Vin, France, ${ }^{\circ} 3$, p.149-154. 